\title{
Mike Robson
}

\section{Eł synspunkt mod Darwin - C.C.A. Goschs kritik af udviklingslæren i 1870'erne}

\section{Indledning}

I de senere år er der sket en glædelig udvikling $\mathrm{i}$ interessen for kortlægningen af modtagelsen af Charles Darwins ideer i Danmark. En bred skildring beregnet for et internationalt publikum findes i Kjærgaard \& Gregersen (2006). Her beskrives det, hvordan debatten fra 1860'erne efterhånden bredte sig på flere og flere fronter og i stigende grad fjernede sig fra det rent naturvidenskabelige perspektiv.

Funder (2002) (se også Juul-Hansen 2000) har undersøgt otte danske videnskabsmænd (seks zoologer og to botanikere) og mener på dette grundlag, at Darwins ideer blev inkorporeret på en relativt fredelig måde. Der var ingen store sammenstød, hverken mellem videnskabsmænd indbyrdes eller mellem videnskabsmændene og samfundet. Videreformidlingen af teorien karakteriseres som åben og konstruktiv. Blandt videnskabsmændene selv konstateres en "indre spændvidde" og dialog. Fra analysen af formidlingen af evolutionsteorien udadtil via undervisning og populære foredrag og artikler konkluderes, at evolutionsteorien tilsyneladende ikke blev anset for kontroversiel eller omstyrtende. Det kontroversielle opstod, når evolutionsteorien blev koblet sammen med andre, mere radikale, samfundsholdninger, og dette tog videnskabsmændene afstand fra. Funders analyse arbejder primært med "accept" og "formidling" af Darwins ideer med vægten lagt på benyttelsen af ideerne i undervisningen, snarere end på benyttelsen af dem i forskningen.

Møller (2000) har undersøgt de danske teologers reaktioner på darwinismen og finder ingen beviser for en særlig bekymring for, eller stillingtagen imod, Darwin. Møller mener, at Darwins ideer kom som blot én af mange udfordringer, som kirken måtte kæmpe med på dette tidspunkt, med den historiske kildekritik som det alvorligste problem. De fleste teologer, finder han, var 
tilbøjelige til at følge filosoffen Rasmus Nielsens standpunkt og fastholde en adskillelse mellem naturvidenskaben og troen, hvorfor de ikke anså det for afgørende at bekæmpe Darwins ideer (se også Robson 2001).

Både Funders og Møllers artikler argumenterer for en rolig modtagelse og assimilering af Darwins tanker i Danmark. Forfatterne afviser det, de opfatter som "konflikt-skolen" (Jespersen 1982; Robson 1982, 1985), som beskriver et modsætningsforhold mellem Darwins tanker og de tidligere herskende fortolkninger af naturen. For at finde den rigtige balance mellem "assimilations" og "konflikt"-fortolkningerne er det nødvendigt bl.a. at afklare hvilke målgrupper man interesserer sig for, og hvordan man f.eks. definerer "assimilation" og "afvisning". I naturfaglig sammenhæng er det også vigtigt at skelne mellem stillingtagen til de to særskilte dele af Darwins hypotese: descendensteorien og selektionsteorien.

I første omgang må en vigtig opgave dog være at inddrage flest mulige relevante bidrag til den danske Darwin-debat. Her er Darwin-arkivet i Århus et lovende fællesværktøj, men materialet er næppe fyldestgørende endnu - mere skal findes frem fra arkiverne, inden vi kan danne et fuldstændigt billede (Darwin-arkivet 2008).

Formålet med denne artikel er at præsentere et markant eksempel på en grundigt argumenteret afvisning af Darwins teorier. Bidraget, som endnu ikke er noteret i Darwin-arkivet, findes i C.C.A. Goschs Udsigt over Danmarks zoologiske Litteratur (Gosch 1870-75). Dette værk udkom, ligesom mange andre bogudgivelser dengang, i hæfter over en flerårig periode. Bibliografien er senere blevet karakteriseret som "Danmarks betydeligste videnskabelige indsats i naturvidenskabens filosofi" (Bay 1933, citeret i Tuxen 1980). Goschs indlæg er vigtigt, fordi det bidrager til vores forståelse af den modstand, teorierne mødte, og til en bedre belysning af det verdenssyn, som lå til grund for mange af datidens naturvidenskabsmænds referenceramme. Indlægget er ikke behandlet i de hidtidige skildringer af modtagelsen af Darwins teorier; Jespersen (1982, s.174) henviser kort til det, uden at gå nærmere ind på argumentationen, og Bræstrup (1980) behandler Goschs bog som eksempel på den prædarwinistiske verdensopfattelse, men uden at diskutere behandlingen af Darwin.

\section{C.C.A. Gosch}

Christian Carl August Gosch (1832-1913) tog magisterkonferens i zoologi i 1855. Han var discipel af entomologen J.C. Schiödte, hvis uforsonlige fejde med en anden berømt dansk zoolog, Japetus Steenstrup, satte et markant præg på zoologiens historie i Danmark, især i perioden fra 1848 indtil Schiödtes død i 1884 (se f.eks. Sand-Jensen 2006). Fejden blev sandsynligvis udløst af 
personlige modsætninger, men udviklede sig efterhånden til en nådesløs kamp om indflydelse og videnskabelig ære, hvor begge parter forsøgte at gøre deres indflydelse gældende hos universitetsfolk og politikere. Kampen blev videreført af eleverne på begge sider indtil langt ind i det 20. århundrede. Mens Schiödte og tilhængerne lagde stor vægt på 'videnskabelig metode' og omhyggelige undersøgelser som gik ned i minutiøse detaljer, var Steenstrup og hans støtter mere til de brede linjer og tværfaglige undersøgelser. Steenstrup var berømt for en række "geniale" opdagelser, af hvilke nogle ganske vist var videnskabelige landvindinger, mens andre viste sig at være eklatante fejlskud. På dette grundlag kunne Schiödte og tilhængere beskylde ham for "dilettanteri".

Gosch tilsluttede sig Schiödte allerede i studieårene, men efter magisterkonferencen rejste han til udlandet, og efter nogle år slog han sig ned i England, hvor han boede indtil sin død. Han samlede på hymenopterer (myrer, bier og hvepse), men brugte ikke sin uddannelse professionelt. Han opretholdt dog en tæt forbindelse med Schiödte gennem brevveksling og besøg i København. I England arbejdede han i begyndelsen som journalist og skrev flittigt i de engelske blade for at fremme Danmarks sag i Slesvig-spørgsmålet. Dette førte til udgivelsen af tre skrifter om dette emne (for den danske stats regning) og til en stilling som attaché ved det danske gesandtskab i London (Collin 1887; Spärck 1936; Henriksen 1937; Tuxen 1980).

Gosch bidrog til fejden mellem Schiödte og Steenstrup, dels med sin zoologiske bibliografi, dels længe efter Schiödtes død med sin biografi om Schiödte (Gosch 1898-1905), hvor han uforbeholdent tilslutter sig Schiödtes parti og tildeler Steenstrup en skurkerolle.

Goschs bibliografi er ikke blot et register over publicerede værker. Bibliografien var planlagt som et kritisk værk, hvor de enkelte forfatteres bidrag beskrives, vurderes og bedømmes: "det maatte fremgaae, ikke blot hvilke Resultater enhver Forfatter har troet at berige Videnskaben med, men ogsaa hvad denne virkelig have vundet ved hans Arbejder" (Gosch 1870-75, bd.1: vii-viii). Ikke overraskende var det Steenstrup, kritikken mest skulle gå ud over. Som grundlag for kritikken helligede Gosch derfor hele første bind af værket til en redegørelse for "de videnskabelige grundsætninger for zoologien". Her opførte han så at sige skanserne, hvorfra de knusende kanonslag mod Steenstrup skulle affyres.

Det er relevant at spørge, i hvor høj grad Goschs tanker er repræsentative for samtidens naturforskere. Det fremgår af Gosch 1898-1905, at hele "Udsigten" blev sendt til Schiödte i manuskript til kommentering og rettelse, og at det desuden var Schiödte, som sørgede for korrekturlæsningen og for kontakten med trykkeriet, mens bogen var i trykken: "Schiödte udtrykte sig som i høi Grad tilfreds med Værket [...] hvori jeg seer et Beviis for, at det i det Hele var 
lykkedes mig [...] at giøre Rede ogsaa for hans videnskabelig-zoologiske Almeenanskuelse, Noget som han for øvrigt ogsaa directe udtalte til mig baade mundtligt og skriftligt." (Gosch 1898-1905, bd. 3: 86-9) Vi kan således opfatte Gosch som repræsentativ for Schiödte og hans tilhængere, og med hensyn til Goschs holdning til Darwins teorier ved vi (se f.eks. Funder 2002), at Schiödte og Steenstrup for en sjælden gang var enige i deres skeptiske indstilling, således at Goschs fremstilling kan antages at gælde for den samlede kreds af idealistiske naturforskere. Med disse forhold på plads kan vi se nærmere på indholdet i Goschs indlæg. Gennemgangen følger dispositionen i Goschs tekst.

\section{Naturvidenskabens vasen og opgave}

Gosch begynder med en kort fremstilling af naturvidenskabens historiske udvikling efterfulgt af en detaljeret redegørelse for den videnskabelige metode $\mathrm{i}$ almindelighed. Formålet er at fastlægge naturvidenskabens opgave og grundlag. I Goschs fremstilling er naturvidenskaberne et udtryk for menneskets trang til at skabe en ordnet forklaring på naturen og de naturlige fænomener. Gosch gør det klart fra starten, at der foreligger både metafysiske og rationelle tilgange til dette arbejde: Verdensforklaringer kan baseres på religion eller på iagttagelse og logik. I Goschs fremstilling af den moderne fortolkning anses naturvidenskaben for empirisk funderet, men hvilende på et metafysisk fundament. Naturvidenskaben beskæftiger sig med sanselige fænomener, dvs. med materien, og udelukker metafysiske fænomener ud over den stiltiende forudsætning, at den materielle verden har en virkelig, selvstændig eksistens.

Undervejs i denne indledning kommer Gosch ind på spørgsmålet om videnskabens forhold til troen, herunder ateisternes forsøg på at tage naturvidenskaben til indtægt for en afvisning af skabelsestroen og troen på en personlig Gud. Darwins ideer nævnes her som et nyt forsøg i denne retning: "den saa kaldte Darwinske Theorie [er blevet] greben med den yderste Begjærlighed [...] af Materialismens Tilhængere" (Gosch 1870-75, bd. 1: 22f). Han præsenterer teorien som en videreudvikling af Jean Baptiste Lamarcks ideer og omtaler kort den udvælgelsesmekanisme, som ifølge Darwin kan føre til dannelsen af nye arter. Gosch nøjes på dette tidspunkt med at kommentere, at teorien "ikke holder Stik, trods de mange virkelig gode Bemærkninger og Iagttagelser, som [Darwins] Bog indeholder". Desuden påpeger han, at teorien, "hvis den var sand, ikke ville rykke Materialismens Sag eet Skridt videre", fordi den ikke forklarer, hvordan den oprindelige urorganisme kunne opstå. Den egentlige behandling af Darwins teori venter til senere i fremstillingen. Goschs historiske indledning afsluttes med en klar opsummering: 
Den Anskuelse, hvortil vi slutte os, er aldeles idealistisk, idet den betragter den sandselige Verden som behersket af en overordnet Alfornuft, for hvis Ideeindhold Naturens Orden, som vi erkjende gjennem Almeensætninger om Samværen og Efterfølge, er et delviist Udtryk. Fra et religiøst Standpunkt betegne vi denne raadende Fornuft som en guddommelig Skabers Attribut. (Gosch 1870-75, bd. 1: 130)

\section{Arterne er uforanderlige}

Under metodeafsnittet (Capitel 2) diskuterer Gosch bl.a. arternes status set i lyset af de videnskabelige arbejdsmetoder, her især induktion og uniformitetsprincippet. I Goschs fremstilling fører disse principper frem til konklusionen, "at Arternes Egenskaber forbliver uforandrede, idetmindste saalænge Naturen overlades til sig selv". Gosch noterer, at man adskillige gange har forsøgt at argumentere for, at arter kan variere, og indrømmer, at dette kan ske inden for "visse snevre Grændser, under Indflydelse af konstig tilveiebragte Forhold". Men, fremhæver han, disse "konstig frembragte Racer" tilhører fortsat den samme art, og "en ny Art, der ikke frembringer frugtbart Afkom med Moderarten, er endnu aldrig fremkommet; Grændsen mellem Race og Art staaer saa fast som nogensinde". Derfor, "saalænge dette er saa, staaer denne Sætning fast for organiske som uorganiske Legemer, at Arterne saalænge de eksistere ere uforandrede" (Gosch 1870-75, bd. 1: 110).

\section{Harmonien i naturen}

Arterne fremviser en tydelig sammenhæng mellem form og funktion, opsummeret i Georges Cuviers "Correlationslov", som hos Gosch udbygges og ophøjes til "Naturens indre Harmonies Princip": "Verden er en levende Eenhed, og [...] alle de Virksomheder, som gaae for sig i den, combinere sig til et Totalresultat" (Gosch 1870-75, bd. 1: 113). Der sker en harmonisk vekselvirkning mellem de forskellige virksomheder, og korrelationsloven bliver især tydelig, når man betragter dyrenes bygningsforhold: "Organismens Individualitet viser sig især deri, at dens Livsvirksomheder danne en harmonisk Eenhed, og $\mathrm{i}$ at den Maade, hvorpaa en af Livets Opgaver løses hos et givet Dyr, staaer i et fuldkomment Hensigtsmæssigheds-Forhold til den Maade, hvorpaa de andre Livsopgaver løses hos dette Dyr" (Gosch 1870-75, bd.1: 140).

Med hensyn til arternes indbyrdes afgrænsning benytter Gosch frugtbarhedskriteriet som det endelige bevis for en arts identitet, selvom man sjældent bruger det i praksis. Artsmedlemmernes indbyrdes frugtbarhed beviser dog, at "Arterne ikke ere blotte Abstractioner, men have en virkelig [...] Selvstæn- 
dighed" (Gosch 1870-75, bd. 1: 187-8). De faste grænser for arternes variationsmuligheder er allerede nævnt. Den historiske dimension i dyreverden, som den kommer til udtryk gennem fossilerne, er meget mangelfuld, siger Gosch, men den viser os "en gradeviis Udviklingsgang, hvorigjennem Dyreideen virkeliggjøres mere og mere fuldkomment" (Gosch 1870-75, bd.1: 192). Desuden findes typer og repræsentanter for adskillige dyreformer, som nu er forsvundet. Disse forsvundne arter tjener til at "belære os om mangt et Punkt, som ellers vilde være blevet os ubekjendt, med Hensyn til hvad man kan kalde Typernes potentielle Indhold d.e. deres Accomodationsmuligheder"' (Gosch 187075, bd. 1: 193).

\section{Hvordan opstod arterne?}

Gosch er således kommet til spørgsmålet om arternes oprindelse og arbejder sig logisk frem mod Darwins teori. Palæontologiens resultater har udelukket den mest rimelige antagelse, at de nuværende arter altid har eksisteret, eller eventuelt er opstået ved én særskilt skabelseshandling. Man må derfor antage, at nye former for liv opstår fra tid til anden, uafhængig af allerede eksisterende livsformer. Hvis dette er tilfældet, må der enten findes en naturvidenskabelig forklaring på dette eller accepteres en rent metafysisk forklaring, f.eks. at der foregår en kontinuerlig eller periodisk tilbagevendende skabelsesproces.

Moderne naturvidenskab anser det ifølge Gosch for usandsynligt, at andre end de laveststående organismer kan opstå fra livløst stof (striden om generatio spontanea). Og selv hvis man accepterer generatio spontanea for laverestående organismes vedkommende, mangler der en forklaring på, hvorfor det tidligere også gjaldt for højerestående organismer, når det nu ikke længere er tilfældet. Gosch konkluderer på dette punkt:

Der staaer da for Øieblikket kun een Vei aaben, nemlig at ansee de organiske Legemers Slægtrækker for oprundne af Individer, der ere komne tilstede ved en eller flere isolerede Skabelsesacter, der tilsammen danne et ialtfald ved Menneskets Skabelse afsluttet System, og som søge deres Forklaring i transcendente Regioner. (Gosch 1870-75, bd. 1: 197)

Det efterlader dog et spørgsmål vedrørende arterne inden for slægtsrækkerne: Har hver eneste art, levende eller uddød, været skabt for sig, eller kan de "i større eller mindre Udstrækning repræsentere Modificationer, der ere indtraadte og fæstnede i Tidens Løb i de oprindelige Slægtrækker"? Hvis dette sidste er tilfældet, vil mange nulevende arter inden for en gruppe eller slægt nedstamme fra en fælles grundform eller stamart. At en sådan proces foregår 
"kan kun bevises ved Paaviisning af fuldstændige gradevise Overgange fra Form til Form. Intet andet Beviis er muligt." (Gosch 1870-75, bd. 1: 197). Gosch antager, at det ville kræve "Menneskealdre" at fremskaffe sådanne beviser, og derfor mener han, at det må være tilladt at arbejde med "Theorier til videre Prøvelse". Det er dog lige så velbegrundet, indtil videre, at fastholde en "reen metaphysisk Forklaring". En sådan metafysisk forklaring kunne være, at en art må variere inden for visse grænser - og at disse grænser selv forandres $i$ tidens løb, således at arten langsomt skifter karakter. Arten gennemgår altså en "gradeviis, lovbunden Udvikling, hvorved Artens ideelle Indhold" realiseres over mange slægtled (Gosch 1870-75, bd. 1: 198).

\section{En ikeke-metafysisk forklaring?}

Men en rent naturvidenskabelig forklaring kunne også tænkes. Man må i så fald søge efter "en Virksomhed, som aldeles automatisk vil forandre Arterne". Det er dette, Darwin har forsøgt at gøre, og Gosch anerkender Darwins fortrin frem for Lamarck, idet begge argumenterer for en "permutationsteori" (dvs. en teori om arternes langsomme forandring), men kun Darwin opstiller en "videnskabelig Theorie" om, hvordan dette kan tænkes at foregå (Gosch 1870-75, bd. 1: 199). Darwins teori refereres som hvilende på to kendsgerninger: At brug eller mangel på brug kan medføre udvikling eller atrofi af et organ eller organsystem, og at denne udvikling eller atrofi kan videregives til afkommet. Med Goschs ord:

hvis til et givet Tidspunkt hele Bestanden af en Art i en vis Localitet underkastes en Indflydelse, som baade vil medføre en eensidig Udvikling eller Atrophie i en eller anden Retning, og paa samme Tid vil begunstige Parring af Individer, som besidde denne eensidige Udvikling, da vil Arten i en saadan Localitet efterhaanden forandre sin Characteer. (Gosch 1870-75, bd. 1: 200)

For at bevise denne hypotese er det ifølge Gosch nødvendigt at påvise, dels at nulevende og tidligere levende arter virkelig har været underkastet denne slags "indflydelser", dels at de opståede forandringer fører til forskelligheder svarende til dem, vi kan iagttage i naturen omkring os. Med hensyn til "indflydelserne" er det Darwins konkurrence- og selektionsteori - "en formodet Competition for Livets Ophold" - som kan føre til "et Udvalg af særegne, vel udrustede Individer, som ville forplante Arten, saaledes som den er udviklet $i$ dem" (Gosch 1870-75, bd. 1: 200) 


\section{Selektionsteorien}

Men Gosch afviser selektionsteorien nærmest uden drøftelse. I hans fremstilling hviler Darwins teori på forudsætningen, at der i hver generation fødes alt for mange individer, hvoraf kun et fåtal kan skaffe næring nok til at overleve. Gosch afviser, at dette er tilfældet: "Sandheden er imidlertid, at hiin formodede stærke Competition for Subsistentsmidler finder aldeles ikke Sted i Naturen, undtagen under ganske særegne Omstændigheder, som ingen almindelig Virkning kunne udøve". Gosch argumenterer for, at talrige dyreformer spiser plantefrø og dyreæg som hovedernæring, og at de få individer, der slipper for at blive spist, ofte bukker under for andre fjender. De plantexdende dyr holdes igen i tømme af rovdyrene, der som bekendt formerer sig langsommere. Og selv når disse begrænsningsmekanismer bryder sammen, f.eks. ved udbrud af insektlarver i skovplantager, genoprettes ligevægten igen "ikke derved at (insektlarverne) tilsidst døe af Sult, men ved en samtidig Forøgelse af deres Fjender, især Snyltehvepserne" (Gosch 1870-75, bd. 1: 201).

I Gosch's udlægning fungerer selektionen kun i de situationer, hvor individerne dør af sult. Hvad det angår, konstaterer han, at der "er fuldt op af Føde for alle Jordens Beboere". Han mener at hvis Darwins havde ret, "saa maatte man hvert Aar finde Mængder af Individer døde og forkrøblede af Sult, men det er ikke Tilfældet". At selektionen også fungerer gennem parasitiske insekters hærgen, rovdyrenes jagt på byttet, planternes kamp om plads og sollys, osv., omtaler han ikke, selvom Darwin lagde vægt på de mange forskellige måder, hvorved selektionen kunne foregå og fremlagde talrige eksempler $\mathrm{i}$ tredje kapitel af Arternes Oprindelse (Darwin 1872: 74-95).

Der findes altså ifølge Gosch ingen kamp om tilværelsen, som Darwin har påstået. Men selv om der gjorde, tilføjer Gosch, "saa vilde der dog ikke resultere en "natural selection", der kunde lede til en Modification af Arten" (Gosch 1870-75, bd. 1: 202). Forklaringen er, at modifikationer kun kan opstå, hvis det er dyrenes "Bygningseiendommeligheder", som giver dem sejren. Men i virkeligheden, siger Gosch, er det ydre, ligegyldige omstændigheder, der afgør om et bestemt individ overlever eller ej, når man kunstigt tilvejebringer en overbefolkning (naturlig overbefolkning kan efter Goschs foregående argumentation ikke opstå). Som eksempel nævner han et plantebed:

Saaer man t.E. et Bed saa tykt, at de unge Planter ikke alle kunne trives, saa vil for det Første ingen af dem komme til den høieste Fuldkommenhed, og det, der afgjør, hvilke der skulle blive store og kvæle de andre, afhænger væsentligt af, hvor dybt Frøet ligger i Jorden, dennes Beskaffenhed paa det enkelte Sted, Fordeling af Lys og Skygge o.sl. (Gosch 1870-75, bd. 1: 202). 
Her får Gosch det modsatte resultat af Darwin, der behandler netop denne problemstilling i tredje kapitel af Arternes Oprindelse, hvor han konkluderer, at faktorer som f.eks. mængden af næringsstof i plantefrøet kan spille en rolle i frøets vellykkede spiring og vækst (Darwin 1872: 93).

Gosch accepterer, at de særlige forhold, som påvirker organismer på en isoleret $\varnothing$, kan føre til modifikationer - "men selv da behøver ingen Modification $[. .$.$] at finde Sted udover hvad man vilde beskrive som local Varietet"$ (Gosch 1870-75, bd. 1: 203). Arterne ville uddø længe før selektionen kunne føre til væsentlige ændringer. Og "den nuværende organiske Verden er ikke et Mosaikresultat af Øfaunaer".

Efter denne afvisning af konkurrence mellem individer af samme art går Gosch videre til konkurrencen mellem forskellige arter, hvoraf der nævnes udvalgte eksempler, bl.a. kampen mellem egen og bøgen "for Exempel i Charlottenlund Skov, hvor prægtige Egetræer døe en langsom Død, kvalte af ynkelige, værdiløse Bøge-Krøblinger" (Gosch 1870-75, bd. 1: 204). Men "hvor er den nye Egeart, som skulde resultere af Darwins natural selection?". Denne slags konkurrence kan føre til udryddelse af arter, siger Gosch, men "Fremkomsten af nye Arter forlanger en anden Forklaring".

Med disse argumenter afviser Gosch selektionsteorien som normal proces i naturens husholdning og fastslår, at under de unormale forhold, hvor selektion eventuelt kan foregå, er resultatet en tilbagegang og udryddelse af arter i stedet for udviklingen af nye.

\section{Andre årsager til forandring?}

Sidste led i Goschs argumentation er at undersøge om en langsom akkumulering af småvariationer kan føre til forskelle mellem arter ligesom dem, man finder i den nuværende dyreverden. Individuelle variationer kan godt forekomme inden for en given art, men med hensyn til Darwins teori er det kun relevant at betragte de variationer, "som tjene Selvopholdelsen paa en saadan Maade, at Individet derved kan faae et Forspring for andre" (Gosch 1870-75, bd. 1: 205). Dette udelukker mange former for variation, mener han; det er ikke en hvilken som helst mindre variation, som kan give en fordel. Der er altid et vist spillerum i organismens udrustning: "Udrustningen er beregnet paa alle de Fordringer, [Dyrets] Levnetsløb kan stille til det ifølge Naturens almindelige Gang, saa at der lades et anseeligt Spillerum”. Der findes altså en vis mulighed for variation. Men en tilfældig variation giver kun fordel, mener Gosch, hvis den overskrider dette indbyggede spillerum, og derved får en "practisk Værdi". Ellers vil den ikke akkumulere. "Men hvor mange Individer 
i en Generation kunne vel ventes at ville besidde en saa stor særlig Udvikling af et eller andet bestemt Organ?" spørger han og minder om, at der skal være i hvert fald to individer, som desuden skal finde hinanden og parre sig, såfremt variationen skal fastholdes i racen - og hele denne proces skal helst gentages et antal gange, ellers går den tabt igen Chancerne for dette, konkluderer Gosch, "er saa overvættes ringe, at det synes absurd, derpaa at ville grunde en Forklaring af Dyrerigets palæontologiske Udvikling" (Gosch 1870-75, bd. 1: 205-206).

Hertil kommer efter Goschs mening, at Darwins forklaring kun er anvendelig på meget nærtstående former. Der kan ikke være tale om at forklare hele dyrerigets udvikling ud fra en enkelt urorganisme. For arter, der i deres livsforløb udviser store forskelle i bygning og livsforhold, forekommer det ham umuligt, at Darwins teori kan anvendes (Gosch 1870-75, bd.1: 206).

\section{Palcontologien}

Tilbage står nu for Gosch at drøfte, om palæontologiens vidnesbyrd kan forklares ved hjælp af Darwins teori. Tankeeksperimenter, hvor man viser, hvordan den ene dyreform kan afledes af en anden ved modifikationer af visse organer, kan naturligvis altid opstilles, siger Gosch. Men for at bevise, at sådanne overgange virkelig har fundet sted, kræves der palæontologiske vidnesbyrd især fund af overgangsformer. Og her konstaterer Gosch, at "af gradeviis Forandring af Slægtrækkernes Indhold, kjendes endnu ingen, blot nogenlunde sikre Spor" (Gosch 1870-75, bd. 1: 207). Det er uvidenskabeligt blot at henvise til, at de fossile lag er ufuldstændige, mener Gosch.

Et andet argument imod udviklingsteorien er, at slægtsrækkernes variationsevne må formodes at være fuldstændig ubegrænset. Kun således kan de store forskelle mellem levende organismer være opstået. Men erfaringerne fra dyre- og planteavl viser det modsatte, anfører Gosch. Variationen går kun på visse typer af forhold, mens de væsentlige anatomiske bygningsforhold forbliver uændrede. Desuden er der heller aldrig fremavlet racer, som er indbyrdes ufrugtbare, dvs. er nye arter efter frugtbarhedskriteriet (Gosch 1870-75, bd. 1: 208).

\section{Goschs konklusion}

Så er Gosch nået til vejs ende; Darwins teori kan afvises. Heldigvis, fordi hvis den havde kunnet sandsynliggøres, ville teorien "i en væsentlig Grad [...] modificere vor almindelige philosophiske Opfattelse af Dyreverdenen". Men Gosch kan konkludere, "at Naturvidenskaben ikke blot ikke tvinger os til, 
men end ikke berettiger os til at modtage dens Consequentser" (Gosch 187075, bd. 1: 209). Gosch afslutter sin gennemgang med en smuk opsummering af den idealistiske verdensfortolkning:

Vi see da Dyrets Idee, Ideen af et organisk Væsen, anviist paa organisk Føde og begavet med selvbestemt Virksomhed, realiseres gjennem et stort Antal Individer, tilhørende Generationsrækker, hvis første Oprindelse er os ubekjendt, og hvoraf hvert Medlem er en organisk Fortsættelse af et Medlem af den foregaaende Generation. [...] Zoologien sammenfatter disse Rækker under Arter [...] og erkjender i disses organiske Bygning en vis Planmæssighed, idet ikke blot Udrustningen svarer paa det Nøieste til Levemaaden, men Udviklingshistorien fra Ægget viser os en gradeviis Uddannelse af Legemet i Overeensstemmelse med de Fordringer, som Dyrets tilkommende Livsomstændigheder ville stille til det. De enkelte Arters Bygningsplaner gruppere sig igjen om visse abstracte Mønstre, der atter samle sig i større Grupper efter deres indbyrdes Overeensstemmelse, saaledes at alle de, hvis Dele svare til hinanden paa den Maade, som vi have betegnet som Homologie, samles i en Række for sig; af saadanne Rækker viser Dyreriget os mindst syv. (Gosch 1870-75, bd. 1: 209-210)

Gosch erkender, at der mangler forklaringer på mange af detaljerne i dette "Idesystem":

Vi kunne ikke angive, hvorfor der just gives disse Grundudtryk for Dyreideen, og ikke andre eller flere. Disse Hovedtyper repræsentere da særskilte Skabertanker, Specialiseringer af Dyrets almindelige Idee, virkeliggjorte i en Skare af underordnede Typer [...]. Disse sidste viser os i deres samlede Heelhed Typens reelle Indhold, eller rettere, hvormeget der er blevet realiseret af dens potentielle Indhold d.e. af de Muligheder, den ideelt indeslutter. Ligesom Dyreverdenen har sin bestemte Plads i det sandselige Verdensalts nuværende Tilstand og Historie, saaledes indtage ogsaa Grundtyperne baade logisk og historisk hver sin bestemte Plads i Dyreideens Virkeliggjørelse i Tid og Rum (Gosch 1870-75, bd. 1: 210211).

Goschs fremstilling af den idealistiske naturvidenskab - eller måske snarere den idealistiske naturhistorie - opbygger en klar og sammenhængende fortolkning af forholdene i naturen, inden for visse selvvalgte rammer. Den nøgterne, materielt orienterede naturvidenskabelige forskning forklares som hvilende på et metafysisk fundament - en antagelse om en harmoni og hensigtsmæssighed i naturen. Denne antagelse erkender han som religiøst eller idealfilosofisk baseret, og Gosch finder ikke anledning til at gøre den til genstand for undersø- 
gelse. Alt $\mathrm{i}$ alt fremstår den idealistiske fortolkning som et stærkt og brugbart redskab for zoologernes vigtigste forskningsaktiviteter i Danmark dengang: sammenlignende anatomi og morfologi, koblet med

faunistiske-systematiske beskrivelser (Juul-Hansen 2000). På disse områder var den helt tilstrækkelig som forklaringsmodel, og der kan ikke have været ret meget incitament for forskere inden for disse områder til at overgå til Darwins teorier.

\section{Et bredere perspektiv: konflik.t eller assimilation?}

Ud fra antagelsen om en harmoni og veltilpassethed i naturen er det forståeligt, at Gosch afviser Darwins teori om selektion og overlevelseskamp. Inden for zoologifaget som Gosch kendte det, dvs. det systematisk-faunistiske og det komparativt morfologiske baseret på sammenlignende formlære (Juul-Hansen 2000), tilbød Darwin ikke noget, som den idealistiske model ikke allerede kunne. Gosch og hans læremester Schiödte - og Steenstrup også i øvrigt - var godt tilfredse med den eksisterende idealistiske fortolkning af naturverden:

Den til enhver Tid paa Jorden levende Dyreverden viser et Hele, hvori enhver Form har sin Plads ligesom Organerne i et Legeme og derfor lige saa lidt som disse kan ændres i nogen betydelig Grad uden Forstyrrelse af det Hele, hvilket udelukker Muligheden af en Omændring af Dyreverdenen i Almindelighed ved isolerede Omændringer af de enkelte Arter af blot tilfældige Aarsager paa en mechanisk Maade (Schiödte, citeret i Gosch 1898-1905, bd. 3: 329).

Uden for disse områder, f.eks. i forbindelse med spørgsmål inden for zoogeografi og palæontologi, kunne Darwins teorier dog tilbyde løsninger, som slet ikke fandtes i den idealistiske fortolkning. Hvor den idealistiske model måtte henvise til metafysiske forklaringer og forestillinger om "skabelsescentre" m.v., tilbød Darwin forklaringsmodeller, som kunne afprøves og udforskes. Et større felt blev således åbnet op for det naturvidenskabelige forskningsprogram.

Som nævnt var der mange, der fandt den idealistiske model mere tiltrækkende end de "mekaniske" aspekter af Darwins teorier. Desuden indebar en antagelse af Darwins teorier potentielle konsekvenser uden for det naturvidenskabelige område - konsekvenser som mange ikke-videnskabsmænd ikke var sene til at fremhæve og udnytte i samfundsdebatten (Kjærgaard \& Gregersen 2006: 165ff; Robson 1982: 231ff). Georg Brandes lagde tonen an under sine "Hovedstrømninger"-forelæsninger i 1871 med sin selvsikre prognose, at "Darwins Lære vil slaae Rettroenhedens Moral til Jorden" (Brandes 1923: 
172), hvorimod filosofiprofessoren Rasmus Nielsen fastholdt, at naturvidenskaben ikke kunne anvendes som våben i religiøse og etiske debatter (Nielsen 1873).

Som påpeget af Møller (2000) blev det et angrebspunkt for de danske teologer imod darwinismen, at den førte til socialdarwinisme, og at den blev brugt som forsvar for liberalismens frie konkurrence. Som biskop Martensen udtrykte det i Den Christelige Ethik: "den svagere Skabning undertrykkes af den stærkere" (Martensen 1871, citeret i Møller 2000: 86). Som Danmark måtte erkende i 1864, kunne en militært svag stat også risikere at blive undertrykt af en stærkere. Blot det at antyde, at "den stærkeres ret" kunne være et gyldigt standpunkt, måtte derfor virke provokerende i Danmark i tiden efter 1864. For patrioten Gosch betød krigen og det smertefulde nederlag en brat afslutning på hans bestræbelser for at vinde England over på Danmarks side. Det var netop i de mørke år efter 1864, "da Begivenhederne - - meget havde indskrænket [min] politisk-literaire Virksomhed", at han kastede sig over et studium af den zoologiske litteratur og derved fik ideen til at skrive sin Udsigt over Danmarks zoologiske Litteratur (Gosch 1898-1905, bd. 3: 82).

\section{Litteratur}

Bay, J.Chr. (1933): Om danskhedens vasen. Holstebro: eget forlag, trykt hos Niels P. Thomsen.

Brandes, Georg (1923): Hovedstromninger i det nittende Aarbundredes Literatur, Forelasninger boldt ved Kobenhavns Universitet i Efteraarshalvaaret 1871; I: Emigrantlitteraturen, Kjøbenhavn: Gyldendalske Forlag.

Bræstrup, F.W. (1980): "Biologernes Tanker før Darwin. Et overset dansk Vidnesbyrd", Naturens Verden, s. 77-80.

Collin, Jonas (1887): "Gosch, Carl Christian August" i Dansk Biografisk Leksikon, 1.udg.

Darwin, Charles (1872, [1859]): Om Arternes Oprindelse ved Kvalitetsvalg eller ved de heldigst stillede Formers Sejr i Kampen for Tilvarelsen. Kjøbenhavn: Den Gyldendalske Boghandel.

Darwin-arkivet (2008): "Materiale om darwinisme i Danmark 1860-1909", http://www. darwin.au.dk/arkivet/bibliographies/earlyliterature, senest besøgt 4. december. 2008.

Funder, Heidi (2002): "En historie om foranderlighed. Evolutionsteorien i Danmark 186080", Historisk Tidsskrift, 102:2, s. 306-337.

Gosch, C.C.A. (1870-1875): Udsigt over Danmarks zoologiske Litteratur, med en indledende Fremstilling af de videnskabelige Grundsatninger for Naturvidenskabens isar Zoologiens Studium, 3 bind, Kjøbenhavn: Hoffenberg, Jespersen \& Fr.Traps Etabl.

Gosch, C.C.A. (1898-1905): Jorgen Christian Schiödte. Et Bidrag til Naturvidenskabens Historie i Danmark $i$ det nittende Aarbundrede, 3 bind, Kjøbenhavn: Gyldendalske Boghandels Forlag. 